Number 10

\title{
GAMBARAN KADAR UREUM DAN KREATININ SERUM PADA PASIEN GAGAL GINJAL KRONIS YANG MENJALANI TERAPI HEMODIALISIS DI RSUD SANJIWANI GIANYAR
}

\author{
D G A Suryawan ${ }^{1}$., I A M S Arjani²., I G Sudarmanto ${ }^{3}$
}

\begin{abstract}
Abstrack
Background The kidneys are responsible for filtering waste from the body such as urea, uric acid, and creatinine. When these organs stop functioning properly, waste builds up to high levels in the blood. In patients with kidney failure are usually equipped with a blood chemistry that urea and serum creatinine as an amplifier diagnosis of the patient's illness. Chronic Kidney Disease (CKD) the progressive loss of function of kidney and patient requires a long treatment in the form of renal replacement therapy. Hemodialysis is one of the renal replacement therapy, during waste products of the body are removed. Patients with kidney failure are associated with increased levels of some biochemical parameters.

Objective the study was aimed to analyze urea and creatinine serum in CKD patients undergoinpre-dialysis revealed abnormal levels and indicated hyperuremic.

Methods this study was aimed to analyzed urea and creatinine serum in CKD patient undergoing hemodialysis in Sanjiwani Hospital. A description study, used purposive sampling methods, involving 30 patients with CKD undergoing hemodialysis. Blood samples were analyzed for urea and creatinin level. Data are presented as table.

Result of this study showed that all samples (100\%) had serum urea and creatinine levels high or exceed the normal limits. While of urea/creatinine levels as many as 20 patients $(66,7 \%)$ had low ratio, 7 patients (23,3\%) had a normal ratio, and 3 patients (10\%) have a high ratio, so that it can be concluded that all patients had hyperuremic.
\end{abstract}

Key words: Urea, Creatinine, Hemodialysis

\section{PENDAHULUAN}

Penyakit ginjal mencakup berbagai penyakit dan gangguan yang mempengaruhi ginjal. Sebagian besar penyakit ginjal menyerang unit penyaring ginjal, nefron, dan merusak kemampuannya untuk menghilangkan limbah dan kelebihan cairan ${ }^{1}$.

Ginjal memiliki peran penting untuk mempertahankan stabilitas volume, komposisi elektrolit, dan osmolaritas cairan ekstraseluler. Salah satu fungsi penting ginjal lainnya adalah untuk mengekskresikan produk-produk akhir atau sisa metabolisme tubuh, misalnya urea, asam urat, dan kreatinin. Apabila sisa metabolisme tubuh tersebut dibiarkan menumpuk, zat tersebut bisa menjadi racun bagi tubuh, terutama ginjal.

1.,2.,3., Jurusan Analis Kesehatan Poltekkes Denpasar Korespondensi : D G A Suryawan ${ }^{1}$, Jurusan Analis Kesehatan, Poltekes Denpasar, Jalan Sanitasi No. 1 Sidakarya, Denpasar-Bali 80224, Indonesia. Telp. +62-361-710 527, Fax. +62-361-710 448

Email : meditoryjournal@gmail.com

Meditory | Vol. 4, No.2, Desember 2016 
Peran yang penting tersebut akan menimbulkan masalah bila ginjal mengalami kegagalan. Hasil metabolit seperti ureum dan kreatinin akan meningkat. Bila fungsi ginjal hanya 5\% atau kurang, maka pengobatan cuci darah atau cangkok ginjal mutlak diperlukan ${ }^{2}$.

Jika penyakit ginjal tidak segera diobati dan ditangani maka kemungkinan akan terjadi gagal ginjal ${ }^{3}$. Kelainan fungsi ginjal merupakan kelainan yang sering terjadi pada orang dewasa. Kelainan fungsi ginjal berdasarkan durasinya dibagi menjadi dua yaitu Gagal Ginjal akut dan gagal ginjal kronik Gagal Ginjal Kronik (GGK) adalah kemunduran dari kemampuan ginjal dalam membersihkan darah dari bahan-bahan racun, yang menyebabkan penimbunan limbah metabolik didalam darah. Gagal Ginjal Akut merupakan suatu keadaan klinis yang ditandai dengan adanya penurunan fungsi ginjal secara mendadak dengan akibat terjadinya peningkatan hasil metabolik seperti ureum dan kreatinin. Kasus GGK saat ini meningkat dengan cepat terutama di negara-negara berkembang. GGelah menjadi masalah utama kesehatan di seluruh dunia, karena selain merupakan faktor risiko terjadinya penyakit jantung dan juga menyebabkan peningkatan angka kematian dan kesakitan. Prevalensi GGK berdasarkan pernah didiagnosis dokter di Indonesia sebesar $0,2 \%{ }^{4}$.
Hingga akhir tahun 2004 terdapat 1.783.000 penduduk dunia yang menjalani perawatan ginjal akibat gagal ginjal, diantaranya $77 \%$ dengan cuci darah, 23\% dengan transplantasi ginjal, disebutkan juga bahwa Indonesia termasuk dengan tingkat penderita gagal ginjal yang cukup tinggi. Menurut data dari Persatuan Nefrologi Indonesia diperkirakan ada 70.000 penderita gagal ginjal di Indonesia, namun yang terdeteksi menderita GGK tahap termil dari mereka yang menjalani cuci darah (hemodialisis) hanya sekitar 4.000 sampai 5.000 saja. Sedangkan menurut data Profil Kesehatan Indonesia (2006), gagal ginjal menempati urutan ke enam sebagai penyebab kematian pasien yang dirawat di rumah sakit di Indonesia 5 .

Kecendrungan kenaikan penderita gagal ginjal juga terlihat dari meningkatnya jumlah pasien yang menjalani terapi hemodialisis, dimana frekuensi hemodialisis per minggu di Indonesia tahun 2012 yaitu frekuensi sekali seminggu sebanyak 3.666, frekuensi 2 kali seminggu sebanyak 7.902, frekuensi 3 kali seminggu sebanyak 783, frekuensi >3 kali seminggu sebanyak 53, sedangkan frekuensi yang tidak teratur sebanyak 4.631. Frekuensi tindakan hemodialisis per minggu di Bali tahun 2012 yaitu frekuensi sekali seminggu sebanyak 814, frekuensi 2 kali seminggu sebanyak 580, frekuensi 3 kali seminggu sebanyak 66, 
frekuensi >3 kali seminggu sebanyak 11, sedangkan frekuensi yang tidak teratur sebanyak $317^{6}$.

Pada pasien gagal ginjal biasanya dilengkapi dengan pemeriksaan darah sebagai penguat diagnosis dari penyakit pasien. Salah satu parameter yang biasanya diperiksakan adalah kadar ureum dan kreatinin serum. Ureum dan kreatinin merupakan prosuk sisa dari metabolisme tubuh. Kadar kreatinin yang tinggi delapan kali lebih umum ditemukan di antara para pengidap hipertensi dibandingkan individu lain yang tekanan darahnya normal. Penyakit ginjal dan hipertensi dapat menjadi penyakit ginjal kronik dan bila tidak diatasi akan berkembang ke gagal ginjal termin yang memerlukan terapi pengganti fungsi ginjal berupa dialisis atau transplantasi ginjal $^{7}$.

Ureum dan kreatinin merupakan senyawa kimia yang menandakan fungsi ginjal masih normal, sementara kreatinin merupakan metabolisme endogen yang berguna untuk menilai fungsi glomerulus. Kreatinin diproduksi dalam jumlah yang sama dan diekskresikan melalui urine setiap hari, dengan nilai normal kreatinin $<1,5$ $\mathrm{mg} / \mathrm{dl}$ dan ureum 10-50 mg/dl. Ureum merupakan produk nitrogen yang dikeluarkan ginjal berasal dari diet protein. Penderita gagal ginjal, kadar ureum serum memberikan gambaran tanda paling baik untuk timbulnya ureum toksik dan merupakan gejala yang dapat dideteksi dibandingkan kreatinin ${ }^{8}$.

Kadar ureum pasien GGK sebelum melakukan hemodialisis masih berada pada level abnormal, dan rata-rata juga mengalami hiperuremik. Kadar ureum dan kreatinin serum ini perlu dimonitor sebagai indikator kerusakan ginjal dan pemeriksaan ini dilakukan setiap akan menjalani terapi hemodialisis, seringkali terlihat bahwa kadar ureum dan kreatinin serum pasien yang akan menjalani terapi hemodialisis kadarnya berubah-ubah, bahkan melebihi kadar normal ${ }^{9}$ Berdasarkan hasil survei di ruangan Unit Hemodialisis RSUD Sanjiwani Gianyar diketahui bahwa, ruang hemodialisis RSUD Sanjiwani Gianyar memiliki kapasitas 12 tempat tidur, dengan 2 shift yaitu pagi dan siang hari. Jumlah pasien gagal ginjal yang menjalani terapi hemodialisis pada tahun 2015 adalah berjumlah 94 orang, dan lamanya terapi hemodialisis dilakukan selama 4 sampai 5 jam dengan jadwal terapi satu kali dan dua kali seminggu. Berdasarkan latar belakang tersebut penulis tertarik untuk mengetahui gambaran kadar ureum dan kreatinin serum pada pasien GGK yang menjalani terapi hemodialisis.

Peranan penting ginjal akan menimbulkan masalah bila ginjal mengalami kegagalan. Hasil metabolisme tubuh akan mengendap dalam tubuh. Bila 
fungsi ginjal hanya 5\% atau kurang, maka pengobatan cuci darah atau cangkok ginjal mutlak diperlukan. Pada pasien gagal ginjal biasanya dilengkapi dengan pemeriksaan kimia darah yaitu ureum dan kreatinin serum sebagai penguat diagnosis. Pada beberapa penelitian kadar ureum dan kreatinin serum pasien GGK sebelum melakukan hemodialisis masih berada pada level abnormal, dan rata-rata juga mengalami hiperuremik.

Penelitian ini bertujuan untuk mengetahui gambaran kadar ureum dan kratinin serum pada pasien GGK yang menjalani terapi hemodialisis di RSUD Sanjiwani Gianyar.

\section{METODE}

Penelitian ini menggunakan jenis penelitian deskriptif dengan rancangan cross sectional yaitu jenis penelitian dimana
Laboratorium Kesehatan RSUD Sanjiwani Gianyar yang bertujuan untuk mengetahui gambaran kadar ureum dan kratinin serum pada pasien GGK yang menjalani terapi hemodialisis di RSUD Sanjiwani Gianyar. Pada penelitian ini menggunakan sampel penelitian yang berjumlah 30 sampel pasien GGK. Teknik sampling sampel pada penelitian ini adalah dengan teknik non probability sampling dengan metode purposive sampling.

\section{HASIL DAN PEMBAHASAN}

\section{Hasil}

Bersadarkan hasil penelitian yang telah dilakukan, kadar ureum dan kreatinin serum pada pasien GGK sebelum menjalani terapi hemodialisis di RSUD Sanjiwani Gianyar berdasarkan jenis kelamin adalah sebagai berikut (Tabel 1):

Tabel 1.Kadar Ureum \& Kreatinin Serum pada Pasien GGK sebelum MenjalaniTerapi Hemodialisis di RSUD Sanjiwani Gianyar berdasarkan Jenis Kelamin

\begin{tabular}{ccccccccc}
\hline \multirow{2}{*}{ Jenis } & \multicolumn{3}{c}{ Kadar Ureum \& Kreatinin Serum (mg/dl) } & \multicolumn{2}{c}{ Total } \\
\cline { 2 - 7 } Kelamin & \multicolumn{2}{c}{ Tinggi } & \multicolumn{2}{c}{ Normal } & \multicolumn{2}{c}{ Rendah } & & \\
\cline { 2 - 7 } & $\sum$ & $\%$ & $\sum$ & $\%$ & $\sum$ & $\%$ & 2 & $\%$ \\
\hline Laki-laki & 24 & 80 & 0 & 0 & 0 & 0 & 24 & 80 \\
Perempuan & 6 & 20 & 0 & 0 & 0 & 0 & 6 & 20 \\
\hline Jumlah & 30 & 100 & 0 & 0 & 0 & 0 & 30 & 100 \\
\hline
\end{tabular}

variabel sebab atau resiko dan akibat atau kasus terjadi pada objek penelitian diukur atau dikumpulkan secara simultan (dalam waktu yang bersamaan) 9 .

Penelitian dilaksanakan di Unit Hemodialisis RSUD Sanjiwani Gianyar dan
Dari hasil penelitian seluruh pasien GGK yang menjalani terapi hemodialisis di RSUD Sanjiwani Gianyar (100\%) memiliki kadar ureum dan kreatinin serum yang tinggi atau melebihi batas normal.Sementara data rasio ureum/kreatinin serum pasien

Meditory | Vol. 4, No.2, Desember 2016 
GGK yaitu sebanyak 20 pasien $(66,7 \%)$ memiliki rasiorendah, 7 pasien $(23,3 \%)$ memiliki rasio normal, dan 3 pasien (10\%) memiliki rasio tinggi.

Pasien GGK memiliki rasio ureum/kreatinin serum normal, dan $10 \%$ pasien GGK memiliki rasio ureum/kreatinin serum tinggi (Tabel 2). diperiksa menggunakan alat Kimia Klinik Biolis Premium 24i di Laboratorium Patologi Klinik RSUD Sanjiwani Gianyar. Sampel yang diperiksa merupakan sampel darah vena dari masing-masing responden yang telah diproses sehingga menjadi serum. Hasil pemeriksaan akan muncul pada layar monitor dengan satuan $\mathrm{mg} / \mathrm{dl}$ yang

Tabel 2. Rasio Kadar Ureum/Kreatinin Serum

\begin{tabular}{cccc}
\hline No & Kategori & Jumlah & Persntase (\%) \\
\hline 1 & Rendah & 20 & 66,7 \\
2 & Normal & 7 & 23,3 \\
3 & Tinggi & 3 & 10 \\
\hline & Jumlah & 30 & 100 \\
\hline
\end{tabular}

Berdasarkan hasil pemeriksaan kadar ureum dan kreatinin serum pada pasien GGK, maka diperoleh kadar ureum dan kreatinin serum, selanjutnya kadar tersebut dibandingkan antara hasil dari kadar ureum serum dengan hasil kadar kreatinin serum setiap sampel, sehingga diperoleh data rasio ureum/kreatinin serum sebanyak pemeriksaan ureum dan kreatinin 66,7\% pasien GGK memiliki ratio ureum/kreatinin serum rendah, $23,3 \%$.

\section{Pembahasan}

Pada pemeriksaan kadar ureum dan kreatinin serum dilakukan secara kuantitatif dengan metode pemeriksaan ureum serum yaitu $U V$ auto fast-rate dan metode pemeriksaan kreatinin serum yaitu Jaffe reaction. Kedua parameter serum ini kemudian disajikan sebagai data penelitian.

1. Distribusi kadar ureum serum pada pasien GGK

Berdasarkan tabel 1 terlihat bahwa hasil penelitian terhadap 30 pasien GGK dapat diketahui bahwa seluruh pasien (100\%) memiliki kadar ureum serum yang tinggi. Hasil ini serupa dengan hasil penelitian di RSU Margono Soekarjo Purwokerto dari 52 pasien, seluruhnya (100\%) mengalami hiperuremik dengan rata-rata kadar ureum serum pasien $151,1 \mathrm{mg} / \mathrm{dl}^{10}$. Kadar ureum dalam darah mencerminkan keseimbangan antara produksi dan eksresi urea. Kadar ureum dalam darah mempunyai nilai rujukan normal yaitu $15-43 \mathrm{mg} / \mathrm{dl}$. Bila kadar ureum darah tinggi maka disebut uremia. Sumber protein tinggi dalam makanan dapat dijumpai pada telur, susu, 
daging, semua jenis kacang-kacangan termasuk olahannya seperti tempe dan tahu yang juga menjadi pemicu peningkatan kadar urea dalam darah, sementara penurunan kadar ureum dapat disebabkan oleh hipervolemia (overhidrasi), kerusakan hati yang berat, diet rendah protein, malnutrisi, kehamilan dan penambahan cairan glukosa intravena yang lama dan juga konsumsi obat fenotiazin ${ }^{11}$.

Ureum dalam darah merupakan unsur utama yang dihasilkan dari proses penguraian protein dan senyawa kimia lain yang mengandung nitrogen. Ureum dan produk sisa yang kaya akan nitrogen lainnya, secara normal akan dikeluarkan dari dalam pembuluh darah melalui ginjal, sehingga peningkatan kadar ureum dapat menunjukan terjadinya kegagalan fungsi ginjal.Berdasarkan penelitian yang telah dilakukan, terlihat dari hasil pemeriksaan kadar ureum serum pada pasien GGK dengan jenis kelamin laki-laki diperoleh data sebanyak 24 sampel (80\%) memiliki kadar ureum serum yang tinggi ( $>43 \mathrm{mg} / \mathrm{dl})$ dengan rata-rata kadar ureum serumnya yaitu 134,8 mg/dl, sementara dari 6 sampel perempuan (20\%), dimana seluruhnya memiliki kadar ureum serum yang tinggi pula (>43 mg/dl) dengan rata-rata kadar ureum serumnya yaitu 130,4 mg/dl.

2. Distribusi kadar kreatinin serum pada pasien GGK
Berdasarkan tabel 1 terlihat jelas bahwa hasil penelitian terhadap 30 pasien GGK dapat diketahui bahwa seluruh pasien (100\%) memiliki kadar kreatinin serum yang tinggi. Hasil ini serupa dengan hasil penelitian di RSU Margono Soekarjo Purwokerto dari 52 pasien gagal ginjal, seluruhnya (100\%) memiliki kadar kreatinin serum tinggi dengan rata-rata kadar $12,6 \mathrm{mg} / \mathrm{dl}^{10}$. Kreatinin merupakan limbah molekul kimia yang dihasilkan dari metabolisme otot. Kreatinin dihasilkan dari keratin, yang merupakan molekul yang sangat penting dalam produksi energi di otot. Kreatinin sebagian besar dijumpai di otot rangka, tempat zat ini terlibat dalam penyimpanan energi sebagai kreatinin fosfat, dalam sintesis ATP dari ADP, kreatinin fosfat diubah menjadi kreatinin dengan katalisasi enzim kreatinin kinase. Reaksi ini berlanjut seiring dengan pemakaian energi sehingga dihasilkan kreatinin fosfat. Pada proses metabolisme kreatinin, sejumlah kecil kreatinin diubah secara ireversibel menjadi kreatin, yang dikeluarkan dari sirkulasi oleh ginjal. Kreatinin diangkut melalui aliran darah ke ginjal. Ginjal menyaring sebagian besar kreatinin dan membuangnya ke dalam urine.Kadar kreatinin akan berubah sebagai respon terhadap disfungsi ginjal, sedangkan kadar ureum akan berubah sebagai respons terhadap dehidrasi dan pemecahan protein. 
Kreatinin serum dan ureum serum kadarnya akan meningkat seiring dengan penurunan kemampuan penyaringan glomerulus. Kadar kreatinin serum ini mencerminkan kerusakan ginjal yang paling sensitif karena dihasilkan secara konstan oleh tubuh. Berdasarkan pemeriksaan kadar kreatinin serum pada pasien GGK dengan jenis kelamin laki-laki diperoleh data sebanyak 24 orang $(80 \%)$ memiliki kadar kreatinin serum yang tinggi (>1,0 $\mathrm{mg} / \mathrm{dl})$ dengan ratarata kadar kreatinin serumnya yaitu 13,1 $\mathrm{mg} / \mathrm{dl}$, sementara dari 6 pasien perempuan, 6 orang (20\%) memiliki kadar kreatinin serum yang tinggi pula $(>1,0 \mathrm{mg} / \mathrm{dl})$, dengan ratarata kadar kreatinin serumnya yaitu 10,6 mg/dl. Kadar kreatininserum dalam darah mempunyai nilai rujukan normal yaitu 0,5 $1,0 \mathrm{mg} / \mathrm{dl}^{12}$.

Kadar ureum dan kreatinin serum pada pasien GGK yang menjalani terapi hemodialisis di RSUD Sanjiwani Gianyar dapat dilihat bahwa setiap pasien GGK yang menjadi sampel pada penelitian ini memiliki kadar ureum dan kreatinin yang berbedabeda. Peningkatan kadar ureum serum akan selalu dibarengi dengan peningkatan kadar kreatini serum juga, hal ini dikarenakan pasien yang menjadi sampel dalam penelitian merupakan pasien dengan riwayat GGK yang penurunan fungsi ginjalnya bersifat irreversible, selain itu pasien yang menjadi sampel pada penelitian ini telah mengidap stadium lanjut gagal ginjal, sehingga jarang akan ditemui kadar ureum dan kreatinin serumnya yang berada dalam batas normal atau dibawah normal. Tingginya kadar ureum dan kreatinin serum dalam darah dapat juga disebabkan oleh tingginya asupan protein pada seseorang, selain itu peningkatan kadar ureum juga dapat disebabkan karena dehidrasi yang berlebihan dan kurangnya suplai darah ke ginjal ${ }^{13}$.

3. Rasio kadar ureum/kreatinin serum pada pasien GGK

Untuk menilai fungsi ginjal, permintaan pemeriksaan ureum dan kreatinin serum selalu disatukan untuk mengetahui rasio dari kedua pemeriksaan tersebut. Rasio ureum/kreatinin serum merupakan indeks yang baik untuk membedakan antara berbagai kemungkinan penyebab uremia.

Berdasarkan hasil pemeriksaan kadar ureum dan kreatinin serum yang telah dilakukan maka diperoleh rasio kadar ureum/kreatinin serum yaitu sebanyak 20 orang pasien $(66,7 \%)$ memiliki rasio ureum/kreatinin serum rendah yaitu dibawah 12, sebanyak 7 orang pasien $(23,3 \%)$ memiliki rasio ureum/kreatinin serum normal (12-20), dan 3 orang pasien (10\%) memiliki rasio ureum/kreatinin serum tinggi lebih dari 20. Dalam penelitian yang dilakukan sebagian besar rasio ureum/kreatinin serum pasien memiliki rasio 
rendah $(<12)$, hal ini dapat dikarenakan pasien tersebut menjalani diet rendah protein, hal ini juga merupakan salah satu syarat pasien gagal ginjal stadium lanjut, dimana mereka diharuskan memperhatikan asupan proteinnya, sehingga tidak memberiksan kerja yang lebih berat terhadap ginjal untuk menyaring sebagian besar protein yang masuk kedalam tubuh melalui makanan, karena makanan yang banyak mengandung protein dapat meningkatkan kadar ureum dalam darah ${ }^{13}$.

Pada penelitian ini juga ditemui 3 orang pasien $\quad(10 \%) \quad$ memiliki rasio ureum/kreatinin serum tinggi, hal ini dapat disebabkan karena dehidrasi, hipovolumia, atau asupan tinggi protein. Dehidrasi pada pasien GGK yang menjalani terapi hemodialisis dapat sering terjadi, hal ini dikarenakan dalam terapi hemodialisis yang dilakukan, pasien akan banyak kehilangan penumpukan cairan dalam tubuhnya, sehingga tidak jarang pasien akan mengalami dehidrasi. Terjadinya dehidrasi menyebabkan ureum dan kreatinin dalam darah menjadi pekat sehingga kadar ureum dan kreatinin serum dalam darah menjadi meningkat yang akan menyebabkan ratio ureum/kreatinin serum mejadi tinggi.

\section{SIMPULAN DAN SARAN}

\section{Simpulan:}

Berdasarkan penelitian yang telah dilakukan, hasil yang diperoleh menunjukkan bahwa kadar ureum dan kreatinin serum pasien rata-rata mengalami hiperuremik, dan seringnya menjalani terapi hemodialisis tidak mencerminkan akan terjadinya penurunan kadar ureum dan kreatinin serum menjadi normal ${ }^{11}$.

\section{Saran:}

Kepada pasien GGK disarankan agar memantau kondisi kesehatannya dan memperhatikan dietnya dengan mengurangi asupan makanan tinggi protein seperti susu, telur, dan kacang-kacangan, sehingga kadar ureum dan kreatinin serumnya dapat terkontrol.

\section{DAFTAR PUSTAKA}

1. Mardyaningsih, D. P. Kualitas Hidup Pada Penderita Gagal Ginjal Kronik yang Menjalani Terapi Hemodialisis di RSUD dr. Soediran Mangun Sumarso Kabupaten Wonogiri. Surakarta: Stikes Kusuma Husada Surakarta, 2014

2. Mubarokah, A., A. Zamridan, dan A. Darmawan. Perbedaan Kadar Hemoglobin, Ureum, Kreatinin Pre dan Post Hemodialisa Selama 3 Bulan Menjalani Hemodialisa di RSUD Raden Mattaher Jambi Periode Desember 2012Maret 2013. Jambi: Universitas Jambi, . 2013

3.Setyaningsih, A., D. Puspita, dan M. I. Rosyidi. Perbedaan Kadar Ureum dan Creatinin Pada Klien yang Menjalani Hemodialisa dengan Hollow Fiber Baru 
dan Hollow Fiber re-use di RSUD Unggaran. Jurnal Keperawatan Medikal Bedah. Volume 1. No 1. Unggaran: Stikes Ngudi Waluyo Unggaran, 2013.

4. Pranata, S., dkk. Pokok-pokok Hasil Riset Kesehatan Dasar (Riskesdas) Provinsi Bali Tahun 2013. Jakarta: Badan Penelitian dan Pengembangan Kesehatan, 2013.

5. Aisyah, J. Karakteristik Penderita Gagal Ginjal Kronik (GGK) yang Dirawat Inap di RS Haji Medan Tahun 2009. Medan: Skripsi Mahasiswa FKM USU Medan, 2011.

6. PERNEFRI. Frekuensi Tindakan Hemodialisis per Minggu di Indonesia Tahun 2011 dalam 5 th Report of Indonesia Renal Registry. Jakarta : Perkumpulan Nefrologi Indonesia (PERNEFRI),2011.

7. Price, S. A., dan L. M. Wilson. Alih Bahasa: B. U. Pendit, dkk. Patofisiologi Konsep Klinis Proses-Proses Penyakit. Volume 2. Edisi 6. Jakarta: Penerbit Buku Kedokteran EGC, 2012.

8. Martini. Hubungan Tingkat Asupan Protein dengan Kadar Ureum dan Kreatinin Darah Pada Penderita Gagal Ginjal Kronik di RSUD Dr. Moewardi Surakarta. Surakarta: Fakultas Ilmu Kesehatan Universitas Muhammadiyah Surakarta, 2010.
9. Runtung, R.,A. Kadir, dan A.Semana. Pengaruh Hemodialisa Terhadap Kadar Ureum, Kreatinin dan Hemoglobin pada Pasien GGK di Ruangan Hemodialisa RSUP Dr.Wahidin Sudirohusodo Makasar, Volume 2 Makasar : Stikes Nani Hasanudin Makasar dan Politeknik Kesehatan Kemenkes Makasar, 2013.

10. Saryono dan Handoyo. Kadar Ureum dan Kreatinin Darah pada Pasien yang Menjalani Terapi Hemodialisis di Rumah Sakit Umum Margono Soekarjo Purwokerto. Vol. 2. Purwokerto: Jurnal Ilmiah Kesehatan Keperawatan, 2006.

11. Sacher, Ronald A., dan R. A. McPHERSON. Alih Bahasa: B. U. Pendit, dan Wulandari. Tinjauan Klinis Hasil Pemeriksaan Laboratorium. Edisi 11. Jakarta: Penerbit Buku Kedokteran EGC, 2004.

12. Sacher, Ronald A., dan R. A. McPHERSON. Alih Bahasa: B. U. Pendit, dan Wulandari. Tinjauan Klinis Hasil Pemeriksaan Laboratorium. Edisi 11. Jakarta: Penerbit Buku Kedokteran EGC, 2004.

13. Arimartini. Desak M. Gambaran Kadar Blood Urea Nitrogen (BUN) dan Serum Kreatinin (SC) pada Usia Lanjut di Banjar Buana Kubu Tegal Harum Denpasar Barat. Denpasar: Politeknik Kesehatan Denpasar, 2013. 